\title{
Progress for research of grape and wine culture in Georgia, the South Caucasus
}

D. Maghradze ${ }^{1, \text { a }}$, A. Aslanishvili ${ }^{1}$, I. Mdinaradze ${ }^{1}$, D. Tkemaladze ${ }^{1}$, L. Mekhuzla $^{1}$, D. Lordkipanidze ${ }^{2}$, M. Jalabadze $^{2}$, E. Kvavadze ${ }^{2}$, N. Rusishvili ${ }^{2}$, P. McGovern ${ }^{3}$, P. This ${ }^{4}$, R. Bacilieri ${ }^{4}$, O. Failla ${ }^{5}$, G. Cola ${ }^{5}$, L. Mariani ${ }^{5}$, S.L. Toffolatti ${ }^{5}$, G. De Lorenzis ${ }^{5}$, P.A. Bianco ${ }^{5}$, F. Quaglino ${ }^{5}$, N. Wales ${ }^{6}$, M.T.P. Gilbert ${ }^{7}$, L. Bouby ${ }^{8}$, T. Kazeli ${ }^{9}$, L. Ujmajuridze ${ }^{10}$, L. Mamasakhlisashili ${ }^{10}$, S. Batiuk ${ }^{11}$, A. Graham ${ }^{11}$, E. Boaretto ${ }^{12}$, A. Cheishvili ${ }^{13}$, and L. Davitashvili ${ }^{14}$

${ }^{1}$ National Wine Agency of Georgia, 6 Marshal Gelovani ave., 0159 Tbilisi, Georgia

${ }^{2}$ National Museum of Georgia, 3 Purtseladze str., 0105 Tbilisi, Georgia

${ }^{3}$ University of Pennsylvania Museum of Archaeology and Anthropology. 3260 South St., Philadelphia, PA 19104, USA

${ }^{4}$ INRA-CIRAD-SupAgro, UMR AGAP, 1334 Montpellier, France

${ }^{5}$ University of Milan. Via Celoria 2, 20133 Milano, Italy

${ }^{6}$ BioArCh, Department of Archaeology, University of York, Heslington, York YO10 5DD, UK

${ }^{7}$ University of Copenhagen, Øster Voldgade 5-7, 1350 Copenhagen, Denmark

${ }^{8}$ Instutut des Sciences de l'Evolition. University of Montpellier. Place Eugène Bataillon, 22, 34095 Montpellier, France

${ }^{9}$ Georgian Wine Association, 12 Mtatsminda str., 0108 Tbilisi, Georgia

${ }^{10}$ Scientific - Research Center of Agriculture, 6 Marshal Gelovani ave., 0159 Tbilisi, Georgia

${ }^{11}$ University of Toronto, Dept. of Near \& Middle Eastern Civilizations, 4 Bancroft Ave, Toronto, Canada

${ }^{12}$ Weizmann Institute of Science, Israel Herzl St 234, Rehovot 7610001, Israel

${ }^{13}$ EHESS [École des hautes études en sciences sociales], CERCEC [Centre d'études des mondes russe, caucasien et centre-européen] boulevard Raspail, 75006 Paris, France

${ }^{14}$ Ministry of Agriculture of Georgia, 6 Marshal Gelovani Ave., 0159 Tbilisi, Georgia

\begin{abstract}
This communication will provide the latest information about the progress of the "Research Project for the Study of Georgian Grapes and Wine Culture", managed by the National Wine Agency of Georgia since 2014. Local and foreign institutions continue to work together with the aim of stimulating multidisciplinary scientific research activity on Georgian viticulture and viniculture and to reconstruct their development from Neolithic civilizations to the present. The project is multidisciplinary in nature, merging contributions from archaeology, history, ethnography, molecular genetics, biomolecular archaeology, palaeobotany, ampelography, enology, climatology and other scientific fields.
\end{abstract}

\section{Introduction}

Georgia - a country of the South Caucasus - is one of the oldest countries in the World or wine production, in which the history of wine making and viticulture began 8000 years ago [1,2]. The country is home to 525 autochthonous varieties of grapes [3] as well as the many populations of wild grapes Vitis vinifera ssp. sylvestris Gmel [4]. This variety of grapes in the South Caucasus' suggest this region as a possible starting point for the domestication of the grapevine. Since approximately 6000 $\mathrm{BCE}$, Georgia has had a continuous history of viticulture and wine making $[5,6]$. This background is the basis for current success of Georgia in the modern wine market, where this small country makes continuous progress using a synthesis of traditional Qvevri winemaking technologies and modern techniques of winemaking and vineyard management.

The research presented here has been made possible by the sustained efforts of various institutions and

a e-mail: david.maghradze@georgianwine.gov.ge stakeholders of the Republic of Georgia as well as representatives of the private sector.

Taking in account the significance of viticulture and winemaking for the country, the National Wine Agency of the Republic of Georgia initiated the "Research Project for the study of Georgian Grapes and Wine Culture" in 2014, continuing until today [6]. This is an international research project constructed through the collaborative work of Georgian and foreign institutions with contributions from Canada, Denmark, France, Israel, Italy, and the USA. The project aims to develop investigations into a variety of research areas including:

- new archaeological excavation of Neolithic settlements;

- the systematic analyses and radiocarbon dating of the grape and other plant remains discovered in the territory of Georgia from various historical periods;

- the biochemical testing of archaeological artifacts for the purposes of identifying tartaric acid and other chemical compounds as markers for Vitis vinifera wines; 
- the characterization of agro-climatic features of Georgia with regards to viticultural and winemaking practices, including the reconstruction of past "Holocene" climate and climatic background for spreading of viticulture from the South Caucasus to other regions;

- the study of ancient DNA from grape seeds from archaeological contexts for the purposes of their comparison to the DNA of the modern grape gene pool (varietal and wild grapevine);

- the presentation of enological and ethnographic heredity of Georgian viticulture and winemaking;

- the analyses of modern practices of viticulture and winemaking for the purposes of their evaluation and argumentation in the historical background.

The aim of this paper is to provide a basic summary of this project and the main results obtained during the last two year-period, representing the rich cultural heritage of grape cultivation and wine making in the Republic of Georgia.

\section{Materials and methods}

\subsection{Structure}

The project is organised into five Working Groups: 1) Archaeology and History; 2) Ancient and modern DNA; 3) Biomolecular archaeology; 4) Georgian viticulture and winemaking; 5) Dissemination and public awareness.

\subsection{Archaeology and history}

\subsubsection{Archaeology}

The archaeological excavations continued at the Neolithic settlements of "Gadachrili Gora" and "Shulaveris Gora" located in the Marneuli district of the Lower Kartli province during the springs of 2017 and 2018 [7]. The sites were occupied during the pottery Neolithic period (c. 6400-4500 BCE in the Greater Near East), and belong to what is known as the "Shulaveri-Shomu culture", dating between 6,000 and 5,200 BCcal. [2,7-13]. The two sites were first identified 1960s, as part of the Lower Kartli Archaeological Expedition of the Georgian State Museum followed by excavations at Shulaveris Gora and a series of Neolithic sites in the region [14,15]. Work at Gadachrili Gora began in 2006-7, and was undertaken again in 2012-5 under the Georgian National Museum. The inaugural season of GRAPE, as part of the Research Project for the Study of Georgian Grapes and Wine Culture took place in 2016 and has continued to the present [see 7].

An archaeological survey was also initiated in 2017 to understand the greater Neolithic landscape of the region and to identify possible wine production areas associated with the identified Neolithic occupation.

The purpose of these excavations is threefold; to provide a rich dataset of archaeological samples originating from the by-products of wine production and consumption during the Neolithic; to preserve and conserve excavated materials for site consolidation and presentation to the public; and to provide cross-cultural educational opportunities for local (Georgian) and foreign (Canadian) undergraduate and graduate students of archaeology.

The excavations have revealed 2 phases of a Neolithic village at Gadachrili (Fig. 1), and 6 phases of occupations

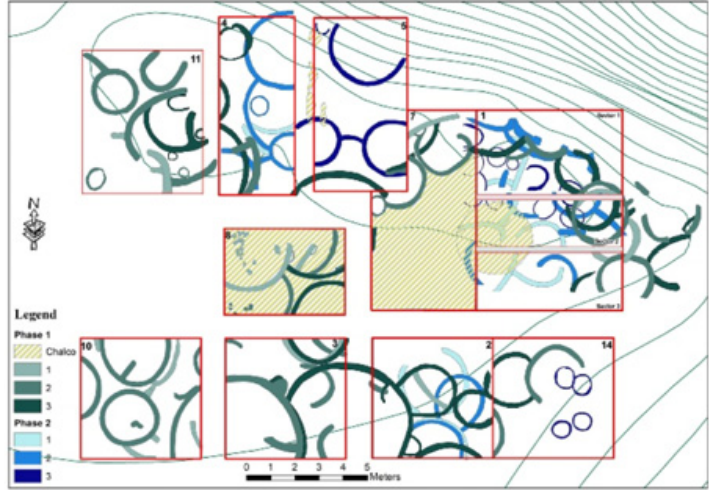

Figure 1. A plan for 2017 excavation of Gadachrili Gora.

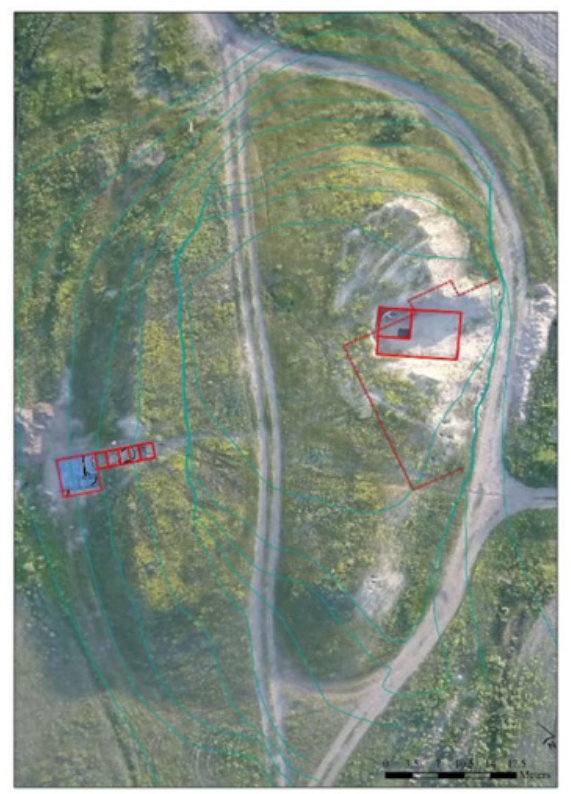

Figure 2. A plan for 2017 excavation of Shulaveris Gora.

at Shulaveris (Fig. 2). These efforts have been successful in providing a more expanded context with which to evaluate recovered samples of pottery (ceramic), lithic (stone tools), faunal (animal bone), paleobotanical (plants/seeds) and geological (soil) and shed light on the economy and way of life in this pivotal period of experimantation in agriculture and horticulture in human history. The results of the study and analysis of all these samples have begun to emerge $[2,16,17]$ and have begun to change our understandings of the Neolithic of the Greater Near East.

\subsubsection{Archaeobotany}

The samples for archaeobotanical analysis were collected from the aforementioned sites of "Gadachrili Gora" and "Shulaveris Gora" from the 2017-8 excavation seasons through a systematic collection program of soil samples, and processed through the floatation method [18]. The samples also were collected from the sites of Gldani (located close to Tbilisi, Middle centuries (Fig. 6), Dzalisi (located $50 \mathrm{~km}$ northwest of Tbilisi, Roman period) and Dedoplis Gora (located in the district of Kareli, $2^{\text {nd }}-1^{\text {st }}$ centuries BC). All samples are analyzed at the archaeobotanical and palynological laboratory under the 
supervision of N. Rusishvili and E. Kvavadze as well as for further radiocarbon dating.

\subsubsection{Morphometry of ancient seeds}

Fifteen archaeological seeds from four archaeological sites in the Kutaisi (980 BC), Dighomi (Hellenistic period), Dateshidzeebi and Tsitsamuri $\left(17^{\text {th }} \mathrm{c}\right.$. AD) regions were selected and the photographed with the idea of their characterization and comparison to modern seeds of Georgian and European domesticated varieties and wild grapes using a "3D morphogeometric analyses" based on the elliptic Fourier transform analysis of dorsal and lateral seed outlines $[19,20]$.

\subsubsection{Palynology}

Soils and artifacts were processed in the palynological laboratory of the Institute of Palaeobiology of the National Museum of Georgia, following standard procedures [21-23]. More than 100 samples obtained from 8 vessels, 9 storage pits, 6 repositories and 15 cultural layers, were studied palynologically from the settlement of "Gadachrili Gora" during 2014-2016 and the results were presented in the paper of McGovern et al. [2]. For the second stage of research 13 samples were obtained during excavation season of 2017, and 25 samples during excavation of 2018 in "Gadachrili Gora" and "Sulaveris Gora". The samples were likewise collected from the vessels, storage pits and mudbricks of walls. In additional, palynologocal analyses were used for research 2 Rhyton discovered in "Dedoplis Gora" archaeological site belonging to Kura-Arax culture (Early Bronze Age).

\subsubsection{Radiocarbon dating}

The examinations of archaeological seeds and woody remains also included radiocarbon dating of selected samples. Thirteen samples of charred grape seeds and charcoals from the National Museum of Georgia, discovered during various archaeological excavation over the past sixty years were examined during the first stage of our research during 2014-2016 and presented in the paper of McGovern et al. [2]. An additional thirteen samples were analyzed in 2017 and 2018, originated mostly from the ongoing archaeological excavations of various sites of Georgia. Samples were analyzed with Fourier Transform Infrared Spectroscopy to define their state of preservation prior to preparation for radiocarbon dating [24]. Samples were then pre-treated to remove the environmental contamination as in [24] and prepared as graphite material and measured at the D-REAMS Radiocarbon dating laboratory at the Weizmann Institute [25].

\subsubsection{French archives}

The old French archives from $18^{\text {th }}$ and $19^{\text {th }}$ century have been searched for information about Georgian grape and wine.

\subsection{DNA study}

\subsubsection{Modern DNA}

A set of around 60 cultivated and more than 100 wild modern grapes of Georgian origins were studied with DNA technologies and compared to a larger dataset published by INRA [26]. First, microsatellite (SSR) fingerprinting with the nine SSR used in the EU-Vitis database (http://www.eu-vitis.de/) was carried out to verify identities, possible synonyms, homonyms and misnomers. Once the list of original genotypes was confirmed, a hybridization capture kit was utilized, defined by INRA and GeoGenetics to capture and sequence stretches of DNA corresponding to around 10.000 known DNA variations in grape (Single Nucleotide Variation, or SNP). An addition 12 Asian Vitis species and one Muscadinia species samples we analyzed to serve as outgroups.

\subsubsection{Ancient $D N A$}

A protocol for extraction of archeological plant remains for further study of ancient DNA was elaborated by the laboratory of "GeoGenetics" at the University of Copenhagen, Denmark (Supervisor T. Gilbert) and tested on materials collected in Georgia by the National Museum of Georgia during archaeological expeditions. Unfortunately, in 2017 a first attempt to recover DNA from archaeological pips from Georgia was unsuccessful. New samples were carefully collected in archaeological excavations in Georgia in 2018.

A collection of 6 archaeological Vitis seeds were processed using state-of-the-art techniques at the paleogenomics laboratory at the University of Copenhagen in 2018. Samples ranged in age from $10^{\text {th }}$ century $\mathrm{BC}$ to $17^{\text {th }}$ Century AD, covering some important stages in early grapevine cultivation in the historic era. DNA isolated from specimens was converted to Illumina libraries for Next Generation Sequencing, and shotgun sequencing was performed. The origin of DNA in specimens was examined using NCBI's BLAST database, quantifying relative proportions of Vitis, bacterial, and fungal DNA. Samples exhibiting high levels of grape DNA were enriched for nuclear SNPs as described above for modern accessions.

\subsection{Biomolecular archaeology}

Twenty-two pottery sherds with seven corresponding soils samples from Neolithic Shulaveri culture Georgia were analysed for possible grape/wine residues in 2014 and 2015 (Figs. 3, 4). The sites included "Gadachrili Gora," "Shulaveris Gora," and "Arukhlo," which was excavated under the auspices of Dr. Sved Hansen (Germany) and Dr. Guram Pirtskhalava (Georgia). Dr. Patrick E. McGovern of the Biomolecular Archaeology Project of the University of Pennsylvania Museum headed the project, in collaboration with Dr. Gretchen R. Hall of the Penn lab, Dr. W. Christian Petersen of the Winterthur Museum's Museum Conservation Laboratory, and Dr. Michael P. Callahan and Dr. Karen E. Smith of NASA's Goddard Space Flight Center. 


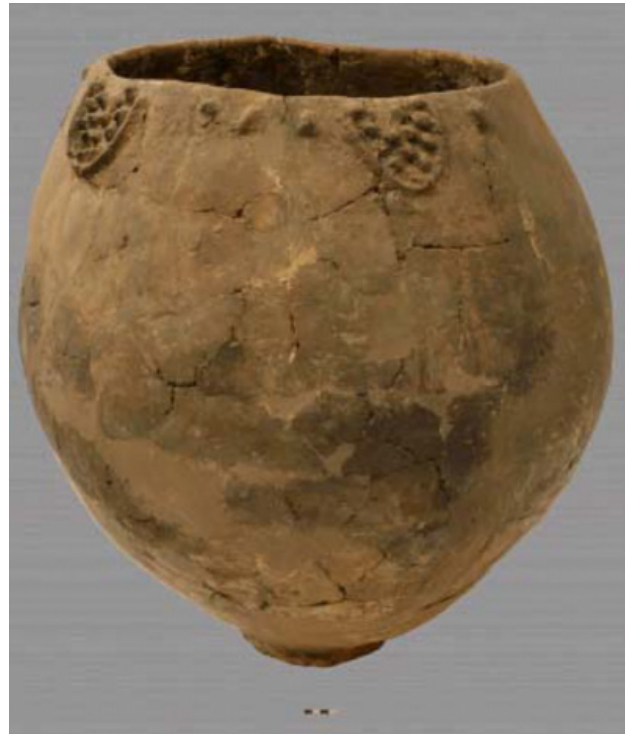

Figure 3. Representative early Neolithic jar from Khramis Didi-Gora (field no. XXI-60, building no. 63; depth, -5.45 to $-6.25 \mathrm{~m}$ ). (By McGovern et al. [2]).

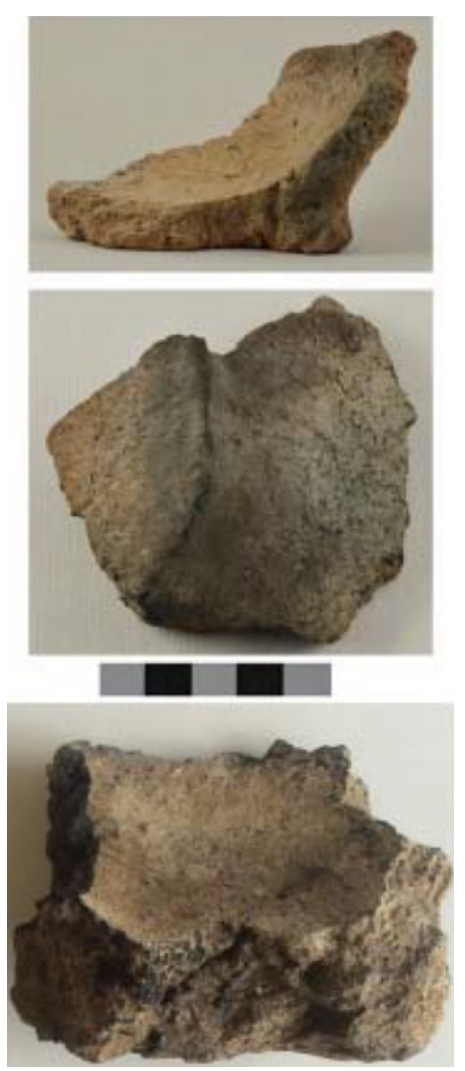

Figure 4. The fragments of the jars included in biomolecular analyses: (A) Jar base SG-16a, interior and cross-section. (B) Jar base SG-782, exterior. (C) Jar base GG-IV-50, interior (By McGovern et al. [2]).

The project enabled us to develop a new, sensitive approach to identifying all the main organic acids in wine, viz. tartaric, malic, citrus, and succinic. Further extraction refinements in our Gas Chromatography - Mass Spectrometry (GC-MS), Fourier-transform Infrared Spectrometry (FT-IR) and Orbitrap Liquid Chromatography Tandem Mass Spectrometric (LC/MS/MS) analyses were also made.
After macroscopic and low-power microscopic examination and photographing, the sherds were sampled for any potential interior residues and other characteristics of interest. Samples were divided up for analysis by FT-IR and GC-MS separately from those for LC/MS/MS with a linear ion trap-Orbitrap detector (Orbitrap LC/MS/MS).

1) Extraction: For FT-IR and GC-MS, the interior surfaces of the sherds were ground down to a depth of 1-3 mm after removing any glue and extraneous soil with distilled water. The powdered residues and accompanying soils were then further ground down by an agate mortar and pestle, as needed, and extracted by our standard chloroform/methanol procedure by boiling in glassware for $3 \mathrm{hr}$., combining the solutions, and evaporating to dryness.

2) FT-IR analyses, databases and searches: The FT-IR data were obtained on Thermo Nicolet spectrometers by diffuse-reflectance on samples mixed with $\mathrm{KBr}$ or on neat (unmixed) samples run using a diamond cell. The FT-IR spectra were searched for "matches" against large databases of relevant natural products and processed organic materials, synthetic compounds, modern wine samples, and "ancient wine reference samples". The latter are residues from ancient vessels which likely originally contained wine, based on strong archaeological criteria or exterior inscriptions which recorded their contents. Samples of special interest are those that provide matches to ancient and modern wine samples, to a high level of probability ( 90 or above on a scale of 100 , according to Thermo Scientific's proprietary OMNIC algorithm).

3) GC-MS analyses, databases and searches: For our experimental methodology in running GC-MS analyses, see McGovern et al. [27] and McGovern et al. [28]. Compound identification was made by retention time and mass spectrum using NIST 05.

4) Orbitrap LC/MS/MS extractions and analyses. For our experimental methodology in running LC/MS/MS analyses, see McGovern et al. [28]. Tartaric acid, malic acid, succinic acid, and citric acid in the sample extracts are identified by (a) correlating sample compounds with known standards at the experimentally determined chromatographic retention times and (b) comparing accurate mass measurements with theoretical exact masses for the organic acids. Elemental compositions are calculated from the deprotonated molecule with introduced limits of carbon (0-30), hydrogen (0-60), nitrogen (0-10), and oxygen (0-15), with a mass tolerance of $2 \mathrm{ppm}$. Peak areas are obtained by either manual integration or by the ICIS peak algorithm in the Xcalibur software package.

5) Bioinformatics evaluation. A bioinformatics approach was key to identifying grape/wine and other natural products which may have been further processed by humans. Biomarkers should be specific to a given geographic area.

\subsection{Viticulture and winemaking}

\subsubsection{Agroclimatology for viticulture}

The agro climatic characterization of Georgia Wine Regions was performed on the base of daily fields of meteorological data for the 1974-2013 period obtained by means of suitable algorithms applied to historical weather station data [29]. 
Climatic features and environmental resources and limitations for grape-growing were taken into account considering:

- Köppen Geiger Classification

- Bagnouls Gaussen Diagram

- Thermo-pluviometric features

- Thermal Resources and Limitations

- Water Resources and Limitations

\subsubsection{Ancient climate reconstruction}

A study on the influence of climate cycles on grapevine domestication and ancient migrations in Eurasia was performed, covering the longitudinal belt ranging from the Iberian Peninsula to Japan, the region often regarded as the preferential pathway for the Holocenic spread of grapevine in Eurasia.

The spectral analysis was based on the two main analytical methods: Maximum Entropy Method [30] and Lomb-Scargle Periodogram [31,32]. Finally, a Student's t-test has been used to evaluate the influence of El Niño on the spectral peaks detected in the selected time series.

\subsubsection{Resistance to Downy Mildew}

Two-year-old plants of the Georgian V. vinifera variety Mgaloblishvili, the international $V$. vinifera variety Pinot noir, and the Vitis interspecifc hybrid variety Bianca were included in a test project for evaluation of resistance towards Plasmopara viticola, the Oomycete causing downy mildew disease [33]. Experimental inoculations were carried out by spraying a sporangia suspension of $P$. viticola to evaluate disease severity and pathogen growth in the leaf tissues by confocal microscopy. At the same time, full transcriptome analysis was carried out on inoculated and non-inoculated leaf tissues and examined to highlight the genes differentially expressed (DEGs) between the two plant treatments. To investigate the resistance response mechanism of Mgaloblishvili to $P$. viticola, the DEGs of Mgaloblishvili, Pinot noir and Bianca were analyzed and compared.

\subsubsection{Ampelography: Cultivars and wild grape}

The investigation of the wild grapevine Vitis vinifera ssp. silvestris - an ancestor of cultivated grape - has a crucial role understanding the biodiversity of this plant, its ampelographic diversity and to develop strategy for its preservation. Several expeditions were organized for its investigation in their natural ecosystems within the country. The mature woody canes of the discovered plants were collected for propagation and the collected specimens were planted within a field repository established in the village of Jighaura (Saguramo) that belongs to the Scientific - Research Center of Agriculture in 2014. The number of genotypes reached was 114 for 2018 .

In 2017 an investigation of wild grapevine in the Jighaura collection originated from Kakheti, Kartli and Lechkhumi provinces of Georgia was started (Fig. 5). The research of 28 genotypes was organized by established methods of ampelography, phenology, eno-carpology, enology, eno-chemistry, ethnobotany and plant pathology in 2017 and 2018 based on the protocols suggested by COST ACTION FA1009 project [34-36]. Two

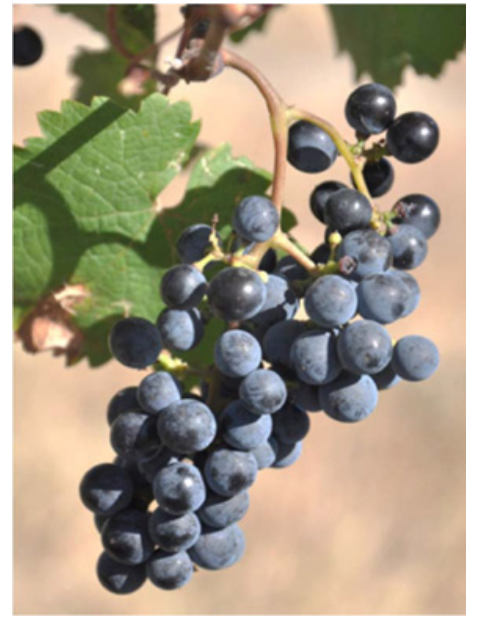

Figure 5. Wild grapevine (Vitis vinifera ssp. silvestris) "Ninotsminda 01" originated from Sagarejo district, Kakheti (source: Jighaura (Saguramo) germplasm repository).

cultivars - Saperavi (N) from Georgia and Cabernet Sauvignon (N) from France - were used as the control varieties [37].

\subsection{Dissemination and public awareness}

The results obtained on Georgian grape and wine culture project have been presented to audiences both inside the country Georgia as well as internationally, by the National Wine Agency. Several venues were utilized: scientific and popular publications, a documentary film, and presentations in wine exhibitions across Europe. In additional, the project's activities has been systematically shared with a wide audience by public outreach events, as well as television and radio broadcasts.

\section{Results and discussions}

\subsection{Archaeology and history group}

\subsubsection{Archaeology}

The archaeological program continued with the excavations of the Neolithic settlments of "Gadachrili Gora" and "Shulaveris Gora", alongside a newly initiated regional survey. The dating of grape remains (seeds, wood) from additional Georgian sites, as well as biometric comparison of ancient seeds of reference collections was also undertaken by specialists. Historians of winemaking investigated artifacts from a wide variety of Georgian historical periods, as well as undertaking the study of historic French archives of the $18^{\text {th }}$ and $19^{\text {th }}$ centuries which discussed Georgia varietals. The results provide new insights on Georgian viticulture and winemaking, its history, and its position in the world of viti- and viniculture.

Archaeological excavations of the early Neolithic agricultural settlments of "Gadachrili Gora" and "Shulaveris Gora", belonging to the "Shulaveri - Shomu Tepe Culture" of South Caucasia (the $6-5^{\text {th }}$ Millennium BC) continued in 2017-8. The excavations continued in most of the same squares from the 2016, with the addition of an additional $50 \mathrm{~m}^{2}$ at Gadachrili with the aims of achieving larger exposures for both occupational phases to clarify 
the changes in the use of space in this agricultural village over time. The excavations at Shulaveris Gora continued a step-trench on the SW side of the mound to re-establish the cultural sequence at the site, and expanded the lowest levels to better understand the earliest levels of occupation of this culture. These new levels, which appear to date to the earliest phase of the Shulaveris-Shomu Cultures revealed new artefacts linked to the earliest viticultural and winemaking activities - specifically ceramic wares, but also soil (palenological) samples (see McGovern et al. [2]). Work in 2018 revealed even earlier levels from which additional samples were collected and which are poised to push the history of viniculture even further back in time.

The archaeological survey endeavored to understand the Neolithic landscape. The excavations produced evidence for the earliest storage and consumption of wine, and was identified at both sites [2], its production areas, however, remained elusive. Finding these production areas were a target of the newly initiated survey. Furthermore, the discovery for evidence of the earliest use of honey [16] and the diversity of animal exploitation, reveals a pattern of a remarkably complex early farming culture that is expanding its subsistence base through the innovative exploitation of new species, and finding new and inventive secondary products. As a result, particular attention paid to the highlands, where caves might have been utilized in the wine production process (as attested in Chalcolithic/ Early Bronze Armenia) [38]. Seventy-eight sites were identified during the 2017-8 seasons with ten dated to the Neolithic period, although occupation at all the sites was probably not contemporaneous in the millennial long Neolithic occupation in the region. No Neolithic cave or hillside sites were identified, suggesting that wine production occurred, if not then in the settlements themselves, then somewhere near the actual source of grapes.

\subsubsection{Seed morphometry}

Seed profile analysis of Vitis seeds using geomorphometrics methods provide valuable insights into the state of domestication and diversity of ancient cultivated grapes. The work is ground into the study of modern pips from wild grapevines and cultivars originating from all-over the distribution area of Vitis in the Mediterranean, Europe and South-West Asia, including Georgia.

The chronology of archaeobotanical samples (more than 450 seeds), extensively validated by radiocarbon dates, ranges from the Early Bronze Age to Modern times. The first domesticated shaped seeds are identified during the Iron Age. From this time onwards wild grapevines continue to be exploited but domesticated grapes predominate including several morphotypes which are, for most of them, close to seed shapes, typical modern cultivars found between Caucasia and Greece.

\subsubsection{Palynological research}

The examination of samples from "Gadachrili Gora" and "Shulaveris Gora" demonstrates that grape pollen was widespread and abundant in many of the excavated early Neolithic contexts at both sites, but is absent from the modern top soils of the sites [2]. The nearest grapevines in the area today are several kilometers away, and any modern pollen would not be able to reach the sites by wind. As a

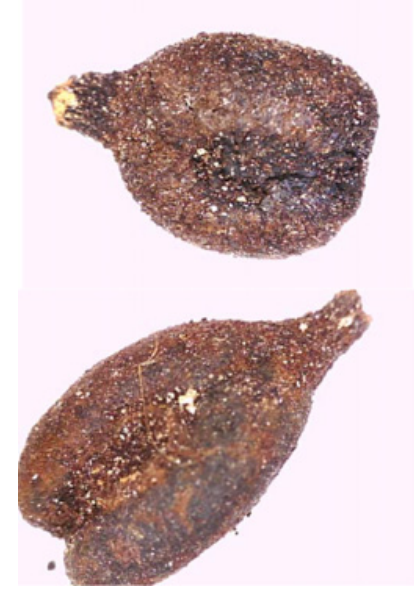

Figure 6. Newly discovered grapevine seeds from wine vessel Qvevri (Gldani site, medieval period).

result, it can be concluded that the pollen identified from the Neolithic contexts are indeed ancient, and not the result of modern contamination. Additionally, agglomerations of pollen suggest that grapes were growing near or even at the sites in the Neolithic period. Supporting evidence for these conclusions is provided by identification of grape starch and grapevine epidermis cells in abundance in the analyzed samples.

Pollen, palynomorphs, and nonpollen microfossils were also extracted by standard palynological analysis (combined with acetolysis) from a fragment of a ceramic storage vessel (serial no. 1828) excavated at Gadachrili Gora, found inside a circular Neolithic building. Its palynological spectrum revealed a combination of tree, cereal, and herbaceous pollen similar to the spectra identified from a stone grinder fragment found in a nearby square. Unlike the ceramic sample, the grinder did not yield any grape starch, grapevine epidermis cells, or remains of fruit flies (Drosophila melanogaster), which are generally attracted to sugar and alcohol. The identification that the jar once contained a liquid grape product, provides additional evidence of wine as grape juice readily ferments into wine [2].

Based on this microbotanical evidence, two reasonable, parsimonious inferences can be made by McGovern et al. [2]: that grapevines were growing close to the Georgian settlements, possibly even inside the villages, and that their fruit was used as a food source. The combined chemical and microbotanical evidence for a grape product inside several liquid storage jars, suggests that grape wine was likely one of the intended products.

Palynological investigation of vessels obtained from the excavations of the Early Bronze Age cemetery of "Dedoplis Gora" (Kura-Araxes culture, c. 3400-2600 $\mathrm{BCE}$ ) revealed that plant pollen was identifiable in abundance in all samples examine. Two zoomorphic rhyton-like (ceremonial drinking vessels) vessels were recovered in the excavations (Fig. 7). The spectrum identified in rhytons were rich with both in quantity and taxonomic composition of pollen and specifically of grapevine (Vitis vinifera) pollen. The grapevine pollen is well preserved, and morphological characteristics of the pollen grains are clearly visible despite the fact that material have been in a fossilized state for nearly 5000 years (Fig. 8). 


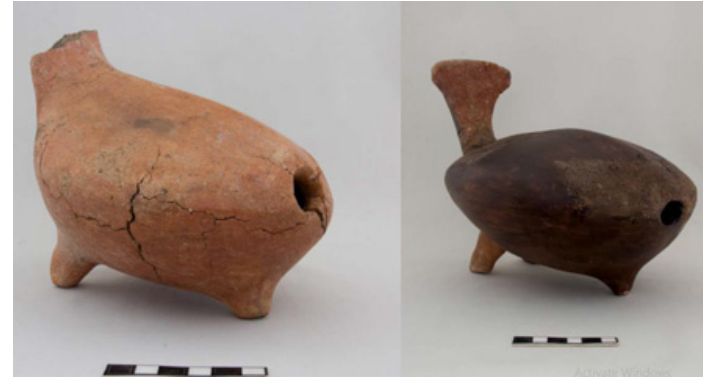

Figure 7. Two zoomorphic Rhytons from "Dedoplis Gora" archaeological site (Kura-Araxes Culture, Early Bronze Age).
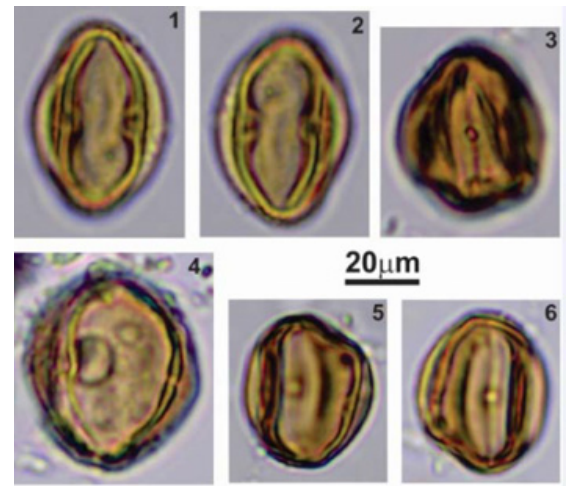

$20 \mu \mathrm{m}$
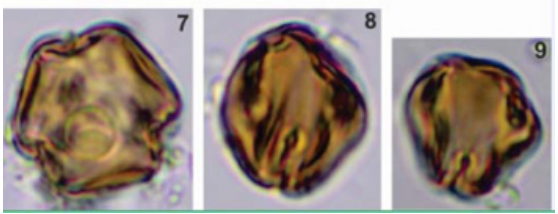

Figure 8. Grapevine pollens described inside of Rhytons ("Dedpolis Gora": Kura-Araxes Culture, Early Bronze Age).

The analysis also revealed that the palynological spectrum of the rhytons' contents are similar to the spectrum identified in samples of modern wine, including: 1) excellent preservation of pollen grains and taxonomic diversity that generally is the result of the preservative characteristics of alcohol; 2) the identification of a significant amount of grape pollen; 3) the presence of pollen of other weeds characteristic of vineyards; 4) the overall dominance of a uniform type of starch in non-palynological remnants; 5) the existence of grape epidermis cells; 6) the identification of an insect (fruit fly Drosephilla melanogaster) hairs. The combination of these factors suggest that wine had been utilized in the rhytons. These two vessels appear to be the oldest zoomorphic rhyton-like vessels so-far recovered in the region. This evidence additionally corroborates the hypothesis of a strong cultural value of wine among the Kura -Araxes people [39].

\subsubsection{Radiocarbon dating}

On the first stage of our study, it was demonstrated that the minimum dates for viniculture during the early Neolithic period in Georgia at Shulaveris Gora and Gadachrili Gora is in the first century of the $6^{\text {th }}$ millennium B.C. More precisely, there is a $68.2 \%$ probability $( \pm 1 \sigma)$ that the dates fall within the range of 5980 B.C. -5900 B.C. or 6020 B.C. -5890 B.C. at a $95.4 \%$ probability $( \pm 2 \sigma)$ [2].

The second set of samples conformed the time period for Gadachrili Gora and Shulaveris Gora to be the end of the $6^{\text {th }}$ Millennium $\mathrm{BC}$ and one samples from Shulaveris Gora demonstrated 6010 B.C. -5810 B.C. at a $95.4 \%$ probability $( \pm 2 \sigma)$ going to the begging of the $7^{\text {th }}$ Millennium B.C. also like in previous set of the samples.

For the samples originated from the other archaeological sites than Neolithic, it was demonstrated the timeperiod since the beginning of the $2^{\text {nd }}$ Millennium B.C. until the $1950^{\text {th }}$. These dates allow to make reconstruction of grapevine history on the territory of the country based on the archaeobotanical materials and with precise radiocarbon method of investigation.

\subsection{Ancient and modern DNA group}

The DNA analyses of ancient grape seeds and plant remains from Georgia are in progress with aims to assess the DNA of ancient varietals against modern Georgian and European wild and domesticated varieties to examine the phylogeny and taxonomic relationships and to infer the hypothesis about grape domestication and the spread of its cultivation around the Mediterranean basin [6]. The genetic information obtained will be merged with the already existing ampelographic characterization and cultivation data of genetic resources, to inform on their distribution, and use in different global contexts.

The comparison of the genetics profiles of ancient and modern materials allow us to retrace the historical origins of the European grapevine diversity and explore its relations with the Caucasian region [40]. While the work based on archaeological remains will progress further as soon as the results of new samples become available, we recently explored first, second and third degree parentships among 783 modern varieties from 44 countries and Georgia [26]. Georgian varieties were found to be linked at first degree of parentship only with other Eastern varieties (examples: Saperavi is parent of Bastardo Magaratchskii and Rubinovyi Magaracha, both Ukrainian varieties; Adreuli Skelkana is parent with Institutis Grdzelmtevana, another Georgian variety; other Georgian-to-Georgian parentships were discovered by [41] but not with European varieties. In addition, several well-known varieties (Badagui noir, Tsolikouri, Usakheluri, Avassirkhva) showed no relationship with European varieties also at second and third degree parentship [26].

On the other hand, Georgian varieties are more diverse both genetically $[26,42]$ and phenotypically [for example, 43] as compared to Western varieties. Their higher individual heterozigosity rate (Fis) and percentage of admixture [26] may indicate that Georgia was historically a place of intense breeding of genotypes both from the wild compartment during domestication and later from the neighbor countries (Central Asia, Iran, Caucasus, Turkey and Greece).

The rare direct parentship relations between Georgian grapes and West European grape may mean that local breeding has been very active through history also in West Europe, blurring traces of common ancestry across geographical regions and generations. Finally, the finding of important Georgian varieties not recently used for breeding in Western Europe should be seen as an encouragement to introduce them in further studies and active breeding schemes. In any case, the study of 
Georgian varieties is very informative about the history of grape domestication and its spread to throughout the World. More work is in progress with a focus on the Balkan genetic resources, as a possible bridge between domestication in the Caucasus and expansion of grape in Europe.

A project initiated by INRA to study the diversity of proantocyandins (PA) in a large collection of Vitaceae included local varieties and wild grape (V. silvestris) from Georgia and results suggest PA composition underwent selection during both domestication and modern breeding [43]. The diversity of PA structure displayed an East-West gradient, with more diversity in the East-Mediterranean and Caucasus region, similar to patterns in genetic diversity.

\subsection{Biomolecular archaeology group}

Chemical analyses by the team revealed ancient organic compounds absorbed into early Neolithic pottery jars and provide the earliest biomolecular archaeological evidence for grape wine and viniculture from the Near East, ca. 5900-5500 BC. The chemical findings are corroborated by climatic and environmental reconstruction, as well as archaeobotanical evidence of grape pollen, starch, and epidermal remains associated with a jar of similar type and date. The discovery of early $6^{\text {th }}$ Millennium BC grape wine in this region is crucial to the subsequent history of wine in the rest of the world.

The chemical detection of tartaric and other organic acids, which are markers of the Eurasian grape (Vitis vinifera) and its products, inside ancient vessels is crucial in establishing the original presence of wine in the vessels. The additional detection of other chemical compounds from botanicals and tree resins, such as diterpenoids and triterpenoids, are used to determine specific winemaking practices in the past, which distinguish the product as most likely wine.

The most notable result from the project to date is a more detailed analysis of Shulaveris Gora 16a in conjunction with analyses of other Neolithic vessels. This is the sherd, which P. McGovern suggested was positive for tartaric acid (TA) many years ago [1] based on less exact methods, and which the media claimed as "proving" that the earliest wine came from Georgia. He cautioned that it was only one sample and more analyses and better methods were needed to be sure. This project has made that possible, and another sherd from Gadachrili Gora (II-9), which appeared promising, has now been shown to be positive for TA by Orbitrap LC/MS/MS. Its TA content is nearly an order of magnitude (10X) than the background soil from the site. Except for succinic acid, it's malic and citric acid contents - all acids associated with TA in grape/wine - were above the background soil contents.

Altogether, five base sherds from Gadachrili and three from Shulaveri were shown to be positive for tartaric acid and other organic acids (malic, succinic, and citric acid) found in grape/wine.

The new Phase III analyses in 2016 definitively established that grape wine was being produced in Neolithic Georgia [2]. It pushes back the date for the earliest wine production in the Near East some 8001000 years: Hajji Firuz, Iran has held this distinction since the publication of McGovern, et al. [44].

\subsection{Georgian viticulture and winemaking group}

\subsubsection{Agroclimatology for viticulture}

The agro climatic analysis of Georgia focused on the current warm phase of the Georgian climate that begun after an abrupt climatic change that took place in 1994 [45]. On the base of the environmental resources and limitations defined for the 12 viticultural regions of Georgia, modern guidelines for the management of vineyards were defined. This relevant body of information is collected in the bilingual (English - Georgian) handbook "Georgian climate analysis for sustainable viticulture".

\subsubsection{Ancient climate reconstruction}

The results of the study on climate cycles [46] are consistent with the hypothesis that Holocenic climate cycles may have influenced the domestication of grapevine in the Subcaucasian area and its subsequent spread in Eurasia.

The results of this study have been presented at two conferences in: i) The seventh National Conference of Italian viticulturist CONAVI, held in Piacenza in July 9-11, 2018 [47]; ii) The 21 ${ }^{\text {st }}$ National Conference of Agrometeorology - AIAM 2018 [48].

\subsubsection{Resistance to downy mildew}

Based on experimental inoculations, confocal microscopy and transcriptomic analyses undertaken in this project, Mgaloblishvili, an autochthonous Vitis vinifera cultivar from Georgia, was found to exhibit unique resistant features against to the agent of downy mildew, Plasmopara viticola [33]. In particular, Mgaloblishvili showed an upregulation of genes encoding for receptors of DAMPs (Damage-Associated Molecular Patterns), pathogen recognition mediated by receptors of PAMPs (PathogenAssociated Molecular Patterns) and effectors, ethylene signalling and synthesis of antimicrobial compounds (e.g. terpenes, glucanases). These genes were downregulated or not affected in Pinot noir and/or Bianca. Further investigations are ongoing on a subset of genes, by using a genome editing (CRISPR-Cas9 system) approach to knock-out their expression and confirm their role in resistance response to $P$. viticola.

\subsubsection{Research of wild grapevine}

Our study of the wild grape is still in progress, including exploration in nature, establishment of a new field collection, and description of genotypes by methods of ampelography and enology.

The main activities for preservation of wild grapevine includes maintenance of a field collection established in the Saguramo grape repository belonging to the Scientific - Research Center of Agriculture since 2014. The wild grape rooting ability was examined and 11 new genotypes were added to this collection during last two years.

The results of the research demonstrated a diversity of studied ampelographic and eno-carpological characteristics. Ethnobotany provided new information about usage of wild grapevine in various field of local life. The wine of wild grape showed quite high enological behaviors. A 
unique genotype was selected with high resistance against Plasmopara viticola fungal diseases. Ampelographic cards for each genotypes studied were produced, including images of grape organs and summarized results of the descriptors. It was demonstrated the high potentiality of this gene pool of wild grape was involved in domestication or breeding actions in the antiquity of Georgia.

\subsection{Dissemenation and public awareness group}

This group is tasked with publication and dissemination of these results to a variety of popular and scientific venues.

Based on the above developments, promotion and dissemination of the project progressed with publications to a variety of popular and scientific media. The exhibition "Georgia - the Cradle of Viticulture" was organized at the Museum of Wine Civilization in Bordeaux, France in 2017 and the documentary film "Georgia - the Cradle of Wine" was prepared.

The local government of Marneuli Municipality and the National Museum of Georgia has organized two public exhibition days for the presentation of the results of the "Gadachrili Gora" archaeological excavations and newly discovered archaeological artifacts to the Mass Media with participation of local authorities such as the Ministry of Culture, Minister of Agriculture, Lower Kartli's regional administration, Wine Association of Georgia and National Wine Agency.

\section{Conclusions}

The contribution of Georgia to science (viticulture, genetics, history, enology, etc.) through permanent and long-term participation, contribution and sharing of resources is quite significant. It has had an impact European and Worldwide understandings about the history of grape cultivation and wine making. This is the main results of this collaboration.

It has been confirmed also, that the results obtained in this research initiative during last years, demonstrate the effectiveness of the multi-disciplinary approach and as well as the importance of a robust investigation into the deep historical roots and rich diversity of viti- and viniculture of the Republic of Georgia.

\section{References}

[1] P.E. McGovern, Ancient Wine: The Search for the Origins of Viniculture (Princeton University, Princeton, 2003/2006)

[2] P. McGovern, M. Jalabadze, S. Batiuk, M.P. Callahan, K.E. Smith, G.R. Hall, E. Kvavadze, D. Maghradze, N. Rusishvili, L. Bouby, O. Failla, G. Cola, L. Mariani, E. Boaretto, R. Bacilieri, P. This, N. Wales, D. Lordkipanidze, Proc. Nat. Acad. Sci. USA (PNAS) 114, E10309 (2017)

[3] N. Ketskhoveli, M. Ramishvili, D. Tabidze, Ampelography of Georgia (Tbilisi: Georgian Academy of Sciences, 1960), p. 439 (in Georgian and Russian)

[4] D. Zohary, M. Hopf, Domestication of Plants in the Old World, 3rd edn. (Oxford University Press, New York, 2000), p. 151

[5] L. Chilashvili, The Vine, Wine and the Georgians (PETITE publisher, Tbilisi, 2004)
[6] D. Maghradze, G. Samanishvili, L. Mekhuzla, I. Mdinaradze, G. Tevzadze, A. Aslanishvili, P. Chavchanidze, D. Lordkipanidze, M. Jalabadze, E. Kvavadze, N. Rusishvili, E. Nadiradze, G. Archvadze, P. McGovern, P. This, R. Bacilieri, O. Failla, G. Cola, L. Mariani, N. Wales, M.T. Gilbert, L. Bouby, T. Kazeli, L. Ujmajuridze, S. Batiuk, A. Graham, L. Megrelidze, T. Bagratia and L. Davitashvili, BIO Web of Conferences 7, 03027 (2016) 39th World Congress of Vine and Wine

[7] S.D. Batiuk, M. Jalabadze, A. Graham, I. Koridze, K. Abu Jayyab, with contributions by C. Savulov. Anatolica 43, 173 (2017)

[8] O. Japaridze, A. Javakhishvili. The Oldest Culture for Farming of Habitants on the Territory of Georgia (Tbilisi, 1971), p. 107 (in Georgian)

[9] V. Ollivier, M. Fontugne, C. Hamon, A. Decaix, C. Hatte, M. Jalabadze, Quaternary Sci. Rev. 197, 267 (2018)

[10] B. Lyonnet, F. Guliyev, L. Bouquet, G. BruleyChabot, A. Anaïck Samzun, L. Pecqueur, E. Jovenet, E. Baudouin, M. Fontugne, P. Raymond, E. Degorre, L. Astruc, D. Guilbeau, G. Le Dosseur, N. Benecke, C. Hamon, M. Poulmarc'h, A. Courcier, Quaternary International 395, 170 (2016)

[11] C. Hamon, M. Jalabadze, T. Agapishvili, E. Baudouin, I. Koridze, E. Messager, Quaternary Int. 395, 154 (2016)

[12] I.G. Narimanov, Kul'tura Drevnejshego Zemledel' chesko - Skotovodcheskogo Naselenija Azerbaidzhana (epokha Eneolita VI-IV tys. do n. e.) (Baku, Elm publ., 1987)

[13] T. Kiguradze, Materialien Zur Allgemeinen und Vergleichenden Archäologie (29. Munich, C.H. Beck, 1986)

[14] A. Javakhishvili, Stroitel'noe Dela I Arkhitektura Poselenij Juzhnogo Kavkaza V-Ill tys. do n.e. (Tbilisi, 1973)

[15] A. Javakhishvili, R. Dolaberidze. Otchet KvemoKartlijskoj Arkheologicheskoj Ekspeditsii (1965-1971 gg) (Report on Kvemo-Kartli Archaeological Expedition (1965-1971) (1975)

[16] E. Kvavadze, et al. (in prep.), J. Archaeolog. Sci. (to be published) (2018)

[17] S. Batiuk et al. (in prep.), The 2017 Gadachrili Gora Regional Archaeological Project (GRAPE), Second preliminary report. Submitted to Paleorient (2018)

[18] S. Sturever, Am. Archailogy 33, 353 (1968)

[19] J.-F. Terral, E. Tabard, L. Bouby, S. Ivorra, T. Pastor, I. Figueiral, S. Picq, J.-B. Chevance, C. Jung, L. Fabre, C. Tardy, M. Compan, R. Bacilieri, T. Lacombe, P. This. Ann. Bot. 105, 443 (2010)

[20] C. Pagnoux, L. Bouby, S. Ivorra, C. Petit, S.M. Valamoti, T. Pastor, S. Picq, J-F. Terral, Veget. Hist. and Archaeobotany 24, 75 (2015)

[21] P.D. Moore, J.A. Webb, M.E. Collinson, Pollen Analysis, 2nd edn. (Blackwell Scientific, Oxford, 1991)

[22] D.R. Piperno, E. Weiss, I. Holst, D. Nadel, Nature 430, 670 (2004)

[23] G.D. Jones, J. Pollination Ecol. 13, 203 (2014)

[24] E. Boaretto, X. Wu, J. Yuan, O. Bar-Yosef, V. Chu, Y. Pan, K. Liu, D. Cohen, T. Jiao, S. Li, H. Gu, 
P. Goldberg, S. Weiner. Proc. Nat. Acad. Sci. (PNAS) 106, 9595 (2009)

[25] L. Regev, P. Steier, Y. Shachar, E. Mintz, E. M. Wild, W. Kutschera and E. Boaretto. Radiocarbon $\mathbf{5 9}$, 775 (2016)

[26] V. Laucou, A. Launay, R. Bacilieri, T. Lacombe, A.-F. Adam-Blondon, A. Bérard, A. Chauveau, M.T. De Andrés, L. Hausmann, J. Ibáñez, M.C. Le Paslier, D. Maghradze, J.M. Martinez-Zapater, E. Maul, M. Ponnaiah, R. Töpfer, J.P. Péros, J.M. Boursiquot, PLoS ONE 13, e0192540 (2018)

[27] P.E. McGovern, G.R. Hall, A. Mirzoian, Danish J. Archaeology 2, 112 (2013a)

[28] P.E. McGovern, B.P. Luley, N. Rovira, A. Mirzoian, M.P. Callahan, K.E. Smith, G.R. Hall, T. Davidson, J.M. Henkin, Proc. Nat. Acad. Sci. USA (PNAS) 110, 10147 (2013b)

[29] G. Cola, L. Mariani, F. Salinari, S. Civardi, F. Bernizzoni, M. Gatti, S. Poni, Agric. Forest Meteoro. 184, 117 (2014)

[30] D.G. Childers (ed.). Modern Spectrum Analysis (Chapter II) (IEEE Press, New York, 1978)

[31] N.R. Lomb, Astrophys. Space Sci. 39, 447 (1975)

[32] J.D. Scargle, Astrophys. J. 263, 835 (1982)

[33] S.M. Toffolatti, G. De Lorenzis, A. Costa, G. Maddalena, A. Passera, M.C. Bonza, M. Pindo, E. Stefani, A. Cestaro, P. Casati, O. Failla, P.A. Bianco, D. Maghradze, F. Quaglino, Sci. Rep. 18, 12523 (2018)

[34] O. Failla, Vitis J. 54, 1 (2015)

[35] L. Rustioni, D. Maghradze, C.F. Popescu, et al., Vitis 53, 219 (2014a)

[36] L. Rustioni, G. Cola, S. Fiori, et al., Acta Hortic. 1032, 253 (2014b)

[37] Sh. Kikilashvili, Study of Genotypes of Wild Grapevine Vitis Vinifera ssp. Sivestris Gmel. in the Jighaura Experimental Station (Diploma for Masterwork. Tbilisi, Caucasus International University), p. 140 (in Georgian)
[38] G.E. Areshian, B. Gasparyan, P.S. Avetisyan, R. Pinhasi, K. Wilkinson, A. Smith, R. Hovsepyan, D. Zardaryan, Antiquity 86, 115 (2012)

[39] S.D. Batiuk, J. Anthropolog. Archaeol. 32, 449 (2013)

[40] J. Ramos-Madrigal, A.K. Wiborg-Runge, L. Bouby, T. Lacombe, J.A. Samaniego Castruita, A.F. AdamBlondon, I. Figueiral, C. Hallavant, J.M. MartinezZapater, C. Schaal, R. Töpfer, B. Petersen, T. Sicheritz-Ponten, P. This, R. Bacilieri, M.T.P. Gilbert, N. Wales, Nature Plants (to be published) (2018)

[41] G. De Lorenzis, R. Chipashvili, O. Failla, D. Maghradze, BMC Plant Biol. 15, 154 (2015)

[42] R. Bacilieri, T. Lacombe, L. Cunff, M. Vecchi-Staraz, V. Laucou, B. Genna, et al., BMC Plant Biol. 13, 25 (2013)

[43] C. Romieu, R. Bacilieri, H. Fulcrand, G. Billerach, C. Marchal, C. Dentraygues, J. Jiang, M. Musayev, M. Reynders, P. Nick, D. Maghradze, M. Grisoni, J.M. Brillouet, Diversity of tannins in a large collection of Vitaceae. Paper presented at the XII International Conference on Grape Breeding and Genetics, Bordeaux 15-20 July 2018

[44] P.E. McGovern, M.M. Voigt, D.L. Glusker, L.J. Exner, Nature 381, 480 (1996)

[45] G. Cola, O. Failla, D. Maghradze, L. Meghrelidze, L. Mariani, 2016. Int. J. of Biometeorol. 61, 761 (2017)

[46] L. Mariani, G. Cola, D. Maghradze, O. Failla, F. Zavatti, Sci. of the Total Environ. 635, 1240 (2018)

[47] D. Maghradze, G. Cola, L. Mariani, O. Failla. Analisi Delle Risorse Agroclimatiche Della Viticoltura Georgiana. The $7^{\text {th }}$ National conference on Viticulture of Italy - Piacenza 9-11.07.2018 (2018)

[48] G. Cola, L. Mariani, D. Maghradze, L. Brancadoro, O. Failla, Analisi Climatica per una Moderna Viticoltura in Georgia Agrometeorology for Rural Development Policies (Bologna: Dipartimento di Scienze Agrarie - Università di Bologna, 2018) 